\title{
Produktivitas dan Pendapatan Usahatani Padi Sawah Tadah Hujan Di Kelurahan Cempaka Kota Banjarbaru
}

\author{
(Productivity and Income of Rainfed Rice Farming \\ In Cempaka Village, Banjarbaru City)
}

\author{
Yan Yozef Agus Suratman \\ Program Studi Agribisnis Fakultas Pertanian Universitas Achmad Yani Banjarbaru \\ yanyozef.agussuratman58@gmail.com
}

\begin{abstract}
ABSTRAK
Optimasi produktivitas padi di lahan sawah merupakan salah satu peluang peningkatan produksi padi nasional. Belum optimalnya produktivitas padi di lahan sawah, antara lain disebabkan oleh berbagai hal khususnya usahatani padi etani menghadapi kendala teknis, sosial, dan ekonomi untuk mengembangkan komoditas padi yang lebih menguntungkan. Praktek manajemen pemupukan sangat mempengaruhi produktivitas, apabila produktivitas diperbesar, sehingga menghasilkan pendapatan yang lebih tinggi dan memungkinkan petani untuk menabung serta mengakumulasikan modal. Pendapatan yang diperoleh seorang petani adalah imbalan yang diperoleh keluarga petani dari penggunaan faktor produksi, tenaga kerja dan modal yang diinvestasikan kedalam bidang usaha. Penelitian ini bertujuan untuk mengetahui (i) produktivitas lahan usahatani padi sawah tadah hujan, (ii) biaya eksplisit, penerimaan, dan pendapatan usahatani padi sawah tadah hujan di Desa Cempaka Kecamatan Cempaka Kota Banjarbaru Provinsi Kalimantan Selatan. Penelitian dilaksanakan dari bulan Maret - Mei 2020. Metode yang digunakan dalam penelitian ini adalah metode survei dengan teknik observasi, dimana teknik pengambilan sampel dilakukan secara simple random sampling dari 217 rumah tangga diambil 14\%, sehingga diperoleh 30 responden. Hasil penelitian menunjukkan bahwa produktivitas lahan usahatani padi sawah tadah hujan adalah $1.265,00 \mathrm{~kg} /$ responden atau 3,5 ton / ha. Biaya eksplisit rata-rata Rp. 1.751.506,83 / responden atau Rp. 4.865.296,74 / ha, penerimaan rata-rata $R$ p. 6.325 .000 / responden atau $R p$. 17.569.444,44 / ha dan pendapatan rata-rata $R p$. 4.573.493,17 / responden atau Rp. 12.704.147,71 / ha.
\end{abstract}

Kata kunci: Produktivitas, pendapatan, usahatani, padi sawah.

\begin{abstract}
Optimization of rice productivity in paddy fields is one of the opportunities to increase national rice production. The not optimal productivity of rice in paddy fields, among others, is caused by various things, especially ethanol rice farming, which faces technical, social, and economic obstacles to develop a more profitable rice commodity. Fertilization management practices greatly affect productivity, if productivity is increased, resulting in higher income and enabling farmers to save and accumulate capital. The income earned by a farmer is the reward that the farming family receives from the use of production factors, labor, and capital invested in the business sector. This study aims to determine (i) the productivity of rainfed lowland rice farming, (ii) explicit costs, revenues, and income of rainfed lowland rice farming in Cempaka Village, Cempaka District, Banjarbaru City, South Kalimantan Province. The research was conducted from March-May 2020. The method used in this study was a survey method with observational techniques, where the sampling technique was carried out by simple random sampling of 217 households taken 14\% so that 30 respondents were obtained. The results showed that the productivity of rainfed lowland rice farming was $1,265.00 \mathrm{~kg} / \mathrm{respondent} \mathrm{or} 3.5$ tons $/ \mathrm{ha}$. The average explicit cost is $R p .1 .751 .506,83$ / respondent or $R p .4 .865 .296 .74$ / ha, the average revenue of $R p$. 6.325.000 / respondent or $R p .17 .569 .444,44 /$ ha and an average income of $R p .4 .573 .493,17$ / respondent or $R p$. 12.704.147,71/ ha.
\end{abstract}

Keywords: Productivity, income, farming, lowland rice.

Article History Submitted: November 18, 2020 Approved with minor revision: December 4, 2020 Accepted: December 12, 2020 Published: December 29, 2020 


\section{PENDAHULUAN}

Pembangunan pertanian terutama ditujukan untuk meningkatkan produksi pangan, mencukupi kebutuhan pangan, guna mempertahankan swasembada beras sekaligus meningkatkan ekspor dan mengurangi impor hasil pertanian dan juga meningkatkan hasil pertanian disektor industri, memanfaatkan pelestarian alam dan lingkungan hidup untuk meningkatkan pertumbuhan pembangunan dipedesaan secara serasi dalam rangka pembangunan daerah (BIP, 2001).

Kenyataan bahwa beras lokal yang dihasilkan dari produk padi spesifik lokal pun banyak beredar dan dijual di pasaran. Tingginya permintaan masyarakat lokal terhadap produk padi lokal spesifik lokasi merupakan stimulan bagi petani untuk tetap mempertahankan menanam komoditas padi lokal. Bahkan yang menarik, bahwa harga beras lokal rata- rata lebih mahal dibanding dengan beras yang berasal dari padi varietas unggul dan yang berasal dari pulau jawa, namun meski harganya mahal, banyak konsumen yang tetap mengkonsumsi beras lokal (Erlina, et. al., 2020).

Optimasi produktivitas padi di lahan sawah merupakan salah satu peluang peningkatan produksi padi nasional. Hal ini sangat dimungkinkan bila dikaitkan dengan hasil padi pada agroekosistem ini masih beragam antar lokasi dan belum optimal. Belum optimalnya produktivitas padi di lahan sawah, antara lain disebabkan oleh: (a) rendahnya efisiensi pemupukan, (b) belum efektifnya pengendalian hama penyakit, (c) penggunaan benih kurang bermutu dan varietas yang dipilih kurang adaptif, (d) kahat hara $\mathrm{K}$ dan unsur mikro, (e) sifat fisik tanah tidak optimal, (f) pengendalian gulma kurang optimal (Umaroh \& Noor, 2019).

Adapun permasalahan pokok disub sektor tanaman pangan khususnya usahatani padi antara lain: (a) Penguasaan lahan semakin sempit karena peningkatan jumlah penduduk dan pewarisan lahan, (b) Penciptaan terobosan teknologi usahatani padi untuk meningkatkan produktivitas dan pendapatan petani semakin sulit, dan (c)
Petani menghadapi kendala teknis, sosial, dan ekonomi untuk mengembangkan komoditas padi yang lebih menguntungkan (Jamaluddin, 2015).

Produktivitas merupakan adalah perbandingan antara hasil produksi yang diperoleh dari suatu kesatuan input dengan kemampuan lahan. Ada beberapa faktor yang dapat mempengaruhi suatu produktivitas yaitu mulai dari kualitas bibit, pupuk, jenis teknologi yang digunakan, modal, infrastruktur dan tingkat pendidikan atau pengetahuan petani. Selain faktor yang disebutkan diatas, praktek manajemen pemupukan dan sebagainya juga sangat mempengaruhi produktivitas. apabila produktivitas diperbesar, sehingga menghasilkan pendapatan yang lebih tinggi dan memungkinkan petani untuk menabung serta mengakumulasikan modal. Pendapatan adalah selisih antara penerimaan dengan biaya eksplisit total (biaya nyata dikeluarkan). Pendapatan yang diperoleh seorang petani adalah imbalan yang diperoleh keluarga petani dari penggunaan faktor produksi, tenaga kerja dan modal yang diinvestasikan kedalam bidang usaha (Pratiwi, et. al., 2018; Triatmoko \& Fitriadi, 2020)

Penelitian ini bertujuan untuk mengetahui (i) produktivitas lahan usahtani padi sawah tadah hujan, dan (ii) seberapa besar biaya eksplisit, penerimaan dan pendapatan dari usahatani padi sawah tadah hujan di Kelurahan Cempaka Kecamatan Cempaka Kota Banjarbaru.

\section{METODE PENELITIAN}

Penelitian ini dilaksanakan di Kelurahan Cempaka Kecamatan Cempaka Kota Banjarbaru Provinsi Kalimantan Selatan. Penelitian ini dilaksanakan selama lebih kurang tiga bulan yaitu dari bulan Maret sampai dengan Mei 2020.

Penelitian ini menggunakan metode survei dengan teknik observasi. Penentuan responden dilakukan dengan teknik acak sederhana (Simple random sampling), dimana setiap petani mempunyai kesempatan yang sama untuk diambil sebagai sampel (Nazir, 2014). 
Jumlah petani yang mengusahakan usahatani padi sawah tadah hujan varitas Siam Lukut sebanyak 217 orang, kemudian dilakukan pengambilan secara acak sederhana (Simple Random Sampling) sebanyak $14 \%$ dari populasi sehingga diperoleh jumlah responden sebanyak 30 responden.

Data yang sudah terkumpul diolah dalam bentuk tabulasi dan selanjutnya dianalisis yang meliputi : biaya, penerimaan, dan pendapatan dari usahatani padi sawah. Pada analisis ini, data yang diperoleh diklasifikasikan menurut jenis dan sifatnya kemudian disesuaikan dengan tujuan dari penelitian ini.

Biaya yang digunakan dalam pengelolaan usahatani padi sawah ini adalah biaya eksplisit. Biaya eksplisit adalah biaya yang nyata dikeluarkan pada pengelolaan usahatani. Secara matematis dapat dirumuskan sebagai berikut :

$$
T E C=\sum_{i=1}^{n} E C(I=1,2,3 \ldots \ldots \ldots n)
$$

dimana :

TEC $=$ Total Explicit Cost $(\mathrm{Rp})$

EC $(\mathrm{i}=1,2,3 \ldots \mathrm{n})=$ Komponen Biaya Eksplisit Usahatani Padi Sawah Tadah Hujan (Rp)

Menurut (Suratman, 2017), untuk mengetahui penerimaan dapat diperoleh dengan menggunakan rumus sebagai berikut :

$$
\mathrm{TR}=\mathrm{P} \times \mathrm{Q}
$$

dimana :

$$
\begin{aligned}
\mathrm{TR}= & \text { Total Revenue } / \text { Penerimaan Total } \\
& \text { Usahatani Padi Sawah Tadah Hujan } \\
& (\mathrm{Rp}) . \\
\mathrm{P}= & \text { Price } / \text { Harga Padi Sawah Tadah } \\
& \text { Hujan }(\mathrm{Rp} / \mathrm{kg}) . \\
\mathrm{Q}= & \begin{array}{l}
\text { Quantity } / \text { Jumlah Produksi Padi } \\
\text { Sawah Tadah Hujan }(\mathrm{kg}) .
\end{array}
\end{aligned}
$$

Besarnya pendapatan suatu usaha dapat diketahui dengan menggunakan rumus berikut (Triatmoko dan Fitriadi 2020): dimana :

$$
\mathrm{I}=\mathrm{TR}-\mathrm{TEC}
$$

$\mathrm{I}=$ Income / Pendapatan Usahatani Padi Sawah Tadah Hujan (Rp).

$\mathrm{TR}=$ Total Revenue / Penerimaan Total Usahatani Padi Sawah Tadah Hujan (Rp).

TEC = Total Explicit Cost / Biaya Eksplisit Total Usahatani Padi Sawah Tadah Hujan (Rp).

\section{HASIL DAN PEMBAHASAN}

\section{Identitas Petani Responden}

Umur petani responden yang menyelenggarakan usahatani padi sawah tadah hujan bekisar antara 25 - 55 tahun. Umur responden yang demikian dapat dikatakan termasuk dalam usia produktif, karena menurut Salladien (1981) bahwa usia produktif berkisar antara $15-54$ tahun. Disamping itu responden yang berusia muda kondisi fisiknya dapat lebih mendukung dibandingkan yang berusia lebih tua dengan demikian diharapkan kegiatan usahatani yang di selenggarakan dapat berhasil (Suratman, 2017).

\section{Tingkat Pendidikan}

Tingkat pendidikan responden di Kelurahan Cempaka yang berusaha padi sawah tadah hujan adalah yang tertinggi tamat Sekolah Dasar (53,33\%) sampai dengan yang terendah tamat SLTA $(13,33 \%)$. Tingkat pendidikan petani responden, nampaknya sebagian masih rendah, hal ini akan berdampak pada usahatani yang diselenggarakannya, karena dengan pendidikan formal akan sangat membantu petani sebagai manajer, dalam mengambil adopsi teknologi baru. Rendahnya pendidikan formal petani mengindikasikan adopsi teknologi belum optimal, dan membutuhkan pengembangan sumberdaya manusia melalui tambahan pendidikan informal untuk melengkapi pengalaman yang telah dimiliki.

\section{Tanggungan Keluarga}

Besarnya jumlah anggota keluarga yang menjadi tanggungan mempengaruhi usaha untuk meningkatkan jumlah produksi 
usahataninya. Jumlah tanggungan keluarga petani responden berkisar antara 1 sampai 5 orang dengan jumlah tanggungan rata-rata adalah 2,6 orang. Yang dimaksud dengan tanggungan keluarga adalah isteri, anakanak dan anggota keluarga lainnya yang menjadi tanggungan responden.

\section{Gambaran Penyelenggaraan Usahatani Padi}

Penelitian terhadap usahatani padi sawah tadah hujan yang dilakukan oleh responden di Kelurahan Cempaka pada musim tanam 2018/2019 sebagai berikut :

Responden seluruhnya menggunakan varietas Siam Lukut. Pada umumnya petani memperoleh benih dengan cara membuat sendiri (hasil panen terdahulu). Rata - rata benih yang digunakan 5,51 kg/petani atau 15,30 kg/ha. Pesemaian dilakukan di atas tanah yang telah dibersihkan dari rerumputan, semak belukar, benih yang telah disiapkan direndam dalam air selama 24 jam kemudian ditanam. Tenaga kerja yang digunakan untuk pesemaian adalah tenaga kerja dalam keluarga. Pesemaian ini terbuat dari lumpur yang diletakan secara merata di atas para (ancak) yang beralaskan daun nipah. Ukuran pesemaian : panjang 2 meter dan lebar 1 meter atau dapat juga dibuat langsung diatas tanah, diatas papan atau di atas rakit. Waktu pesemaian dimulai pada permulaan musim hujan.

Pengolahan tanah dilakukan dengan cara membersihkan lahan dari semak atau jerami dengan jalan mencangkul. Tenaga kerja yang digunakan terdiri dari tenaga kerja dalam keluarga dan luar keluarga.

Waktu penanaman padi yang dilakukan petani contoh pada bulan Desember/Januari (tergantung musim) . Setiap lubang tanam diperlukan bibit $2-3$ batang dengan jarak tanam $25 \times 25 \mathrm{~cm}$. Pada umur 25 hari bibit telah tumbuh kuat dan tinggi sehingga telah dapat ditanam pada lahan sawah dengan kedalaman genangan air $5-10 \mathrm{~cm}$. Penanaman dengan menggunakan asak. Pemeliharaan yang dilakukan petani meliputi kegiatan :

Penyiangan atau pembersihan dilakukan pada saat tanaman berumur 1-
2 bulan. Maksud dari penyiangan adalah untuk membersihkan tanah dari rumputrumput liar dan sekaligus menggemburkan tanah dan juga pencegahan terhadap serangan hama dan penyakit. Penyiangan dilakukan dengan mencabut rumput yang ada disekitarnya tanaman dengan tangan (manual). Umumnya penyiangan dilakukan 2 kali saat tanaman berumur 30 hari dan 50 hari.

Pemupukan yang dilakukan pada pertanaman ini responden menggunakan pupuk Urea dan Ponska. Pemupukan dilakukan 1 kali selama musim tanam. Jumlah pupuk Urea yang digunakan ratarata $34,54 \mathrm{~kg} / \mathrm{ha}$, pupuk Ponska rata-rata sebesar 34,55 kg/ha. Cara pemberian pupuk Urea dan Ponska diberikan bersamaan pada saat tanam.

Pemberantasan hama dan penyakit dilakukan beberapa kali dalam satu musim tanam. Pengendalian hama tikus dan walang sangit dengan menggunakan Klerat dan Matador. Penggunaan Klerat sebesar 345,37 gram/ha. Penggunaan Matador ratarata sebesar 345,37 cc/ha.

Panen biasanya dilakukan pada bulan Juni atau Juli atau pada saat umur tanaman sudah cukup tua. Panen dilakukan di lahan dengan ciri-ciri, bulir padi kelihatan masak merata, daun bendera berwarna kuning dan kering. Alat yang digunakan untuk pemanenan adalah ani-ani dan perontokan dilakukan dengan menginjak padi yang masih bertangkai dan diberi alas tikar di bawahnya.

Padi yang telah dipanen segera dirontokan dan dikeringkan. Kemudian dibersihkan dengan alat gumbaan agar hasil panen bersih dari kotoran dan butir hampa yang terbawa saat panen. Tujuan pengeringan adalah menurunkan kadar air gabah dari 23 - $27 \%$ menjadi 13-14\% agar dapat disimpan lama, untuk meningkatkan kualitas gabah menyiapkan gabah untuk pengelolaan selanjutnya dan memperkecil biaya transport. Pengeringan hasil panen harus dilakukan dengan sebaik-baiknya. Pengeringan yang kurang merata akan menyebabkan keretakan pada gabah dan sebaliknya terlalu kering tidak baik untuk digiling, karena mudah pecah. 
Gabah kering memerlukan tempat penyimpanan. Faktor-faktor yang perlu diperhatikan dalam penyimpanan adalah tempat dan caranya, yaitu gabah harus bersih, sehat dan kering, tidak boleh berdekatan dengan insektisida dan pupuk, bangunan dilengkapi dengan ventilasi. Penyimpanan dalam jumlah kecil disimpan dalam karung.

\section{Produksi dan Produktivitas}

Produksi yang diperoleh dari usahatani padi sawah tadah hujan dari 30 responden dengan luas lahan rata-rata 0,36 ha adalah produktivitas lahan usahatani padi sawah tadah hujan sebesar $3.513,89 \mathrm{~kg} / \mathrm{ha}$ (3,51 ton/ha). Produktivitas menggambarkan antara hasil jumlah barang dan jasa yang diproduksi dengan sumber tenaga kerja, modal, bahan baku, dan lain - lain yang dipakai untuk menghasilkan barang tersebut. Produktivitas juga ditunjang ketersediaan lahan sawah dan ini mernjadi dua variabel penting yang dapat memberikan dampak secara signifikan terhadap sistem produksi beras secara keseluruhan. Produktivitas padi-padi lokal di kecamatan Gambut adalah 3.6 Ton/Ha (BPP Gambut dalam usaha peningkatan Produksi Padi dapat ditempuh melalui perbaikan penanganan panen dan pasca panen yang ditujukan untuk menekan kehilangan hasil selama panen dan pasca panen tersebut (Triatmoko \& Fitriadi, 2020; Wibowo, 2016).

\section{Biaya Penyelenggaraan Usahatani Padi}

\section{Pajak Lahan}

Lahan yang digunakan dalam penyelenggaraan usahatani padi ini adalah milik sendiri. Biaya lahan yang diperhitungkan adalah pajak lahan yang harus dibayar oleh petani atas kepemilikan lahan untuk satu tahun. Besar biaya pajak tanah yang berlaku sebesar Rp. 10.000/ha/tahun. Biaya pajak lahan yang dikeluarkan petani rata-rata sebesar Rp. 2.664,29/responden.

\section{Biaya Tenaga Kerja Luar Keluarga}

Untuk melaksanakan kegiatan usahatani tentunya diperlukan tenaga kerja, baik tenaga kerja upahan maupun tenaga kerja dalam keluarga. Kegiatan yang dilakukan oleh tenaga kerja upahan (TKLK) dalam kegiatan usahatani padi adalah pengolahan tanah, penanaman, pemupukan, penyiangan, panen dan pengangkutan. Besarnya rata-rata biaya tenaga kerja luar keluarga (TKLK) dalam kegiatan usahatani padi rata-rata sebesar Rp. 1.183.000,00/responden atau sebesar Rp. 3.286.111,11/ha. Untuk lebih jelasnya mengenai rincian biaya penggunaan tenaga kerja luar keluargaresponden dapat dilihat pada Tabel 1.

Tabel 1. Biaya Tenaga Kerja Luar Keluarga Rata-Rata Pada Usahatani Padi Sawah Tadah Hujan di Kelurahan Cempaka.

\begin{tabular}{clcc}
\hline No. & \multicolumn{1}{c}{ Uraian } & Biaya Rata-Rata $(\mathrm{Rp})$ & Persentase $(\%)$ \\
\hline 1. & Pengolahan lahan & $351.666,67$ & 17,84 \\
2. & Penanaman & $406.666,67$ & 17,84 \\
3. & Pemupukan & $101.333,33$ & 6,42 \\
4. & Penyiangan & $210.666,67$ & 13,36 \\
5. & Panen & $310.666,67$ & 19,70 \\
6. & Pengangkutan & $266.666,67$ & 16,91 \\
\hline \multicolumn{2}{r}{ Jumlah } & $1.647 .666,67$ & 100,00 \\
\hline
\end{tabular}

Sumber: Hasil Pengolahan Data Primer, 2020.

Dari Tabel 1, dapat diketahui bahwa biaya terbesar pada biaya penanaman yaitu sebesar Rp. 406.666,67/petani $(25,78 \%)$ dan biaya terendah pada kegiatan pemupukan yaitu sebesar Rp.101.333,33/petani (6,42\%).

\section{Sarana Produksi}


Biaya sarana produksi yang dikeluarkan dalam kegiatan usahatani padi meliputi biaya penggunaan benih, pupuk dan pestisida. Total sarana produksi yang digunakan petani sebesar
2.336.900,00 dengan biaya rata-rata sebesar Rp. 77.896,67/responden atau sebesar Rp. 216.379,63/ha. Data lebih rinci lihat pada Tabel 2.

Tabel 2. Biaya Sarana Produksi Rata-rata Pada Usahatani Padi Sawah Tadah hujan di Kelurahan Cempaka.

\begin{tabular}{clcc}
\hline No. & \multicolumn{1}{c}{ Uraian } & Sarana Produksi Rata-Rata $(\mathrm{Rp})$ & Persentase $(\%)$ \\
\hline 1. & Benih & $27.541,67$ & 35,36 \\
2. & Pupuk Urea & $21.136,67$ & 27,13 \\
3. & Pupuk Ponska & $21.136,67$ & 27,13 \\
4. & Kleret & $3.108,33$ & 3,99 \\
5. & Matador & $4.973,33$ & 6,36 \\
\hline & Jumlah & $1.647 .666,67$ & 100,00 \\
\hline
\end{tabular}

Sumber : Hasil Pengolahan Data Primer, 2020.

Dari Tabel 2, dapat diketahui bahwa biaya terbesar pada penggunaan sarana produksi adalah biaya benih yaitu sebesar Rp 27.541,67/responden (35,36\%) atau sebesar Rp. 76.504,63/ha dan biaya terendah pada penggunaan Klerat sebesar Rp. 3.108,33/responden $(3,99 \%)$ atau sebesar Rp. 8.634,26/ha.

\section{Penyusutan Alat danPerlengkapan}

Biaya alat dan perlengkapan diperhitungkan dengan menggunakan garis lurus (Straihgt Line Methode), yaitu nilai baru besarnya harga pembelian dikurangi nilai sisa dibagi umur atau lamanya pemakaian alat dan perlengkapan tersebut, sedangkan nilai sisa dianggap nol (Fadholi, 1993).

Biaya penyusutan alat/perlengkapan yang digunakan dalam kegiatan usahatani padi sawah tadah hujan rata-rata sebesar Rp. 22.391,11/responden atau sebesar Rp. 62.197,53/ha. Data lebih rinci lihat pada Tabel 3.

Tabel 3. Biaya Penyusutan alat dan Perlengkapan Rata-rata Pada Usahatani Padi Sawah di Kelurahan Cempaka.

\begin{tabular}{clcc}
\hline No. & Alat dan Perlengkapan & Biaya Penyusutan Rata-Rata $(\mathrm{Rp})$ & Persentase $(\%)$ \\
\hline 1. & Tajak & $3.385,42$ & 15,12 \\
2. & Cangkul & $3.385,42$ & 15,12 \\
3. & Parang & $1.333,33$ & 5,95 \\
4. & Asak & 750,00 & 3,35 \\
5. & Ani-ani & 230,00 & 1,03 \\
6. & Karung & $3.195,83$ & 14,27 \\
7. & Tikar & $4.277,78$ & 19,10 \\
8. & Gumbaan & $2.083,33$ & 9,30 \\
9. & Hand Sprayer & $3.750,00$ & 16,75 \\
\hline & Jumlah & $22.391,11$ & 100,00
\end{tabular}

Sumber : Hasil Pengolahan Data Primer, 2020.

Dari Tabel 3, dapat diketahui bahwa biaya terbesar pada biaya penyusutan alat dan perlengkapan pada penggunaan tikar yaitu sebesar Rp. 4.277,78/responden (19,10\%) dan biaya terendah pada penggunaan 
Ani-ani sebesar Rp. 230,00/responden $(1,03 \%)$.

\section{Biaya Eksplisit}

Dari hasil perhitungan dan uraian di atas, maka diperoleh besarnya biaya eksplisit sebesar Rp. 52.545.204,76 dengan biaya eksplisit rata-rata sebesar Rp. 1.751.506,83/responden atau sebesar Rp. 4.865.296,74/ha. Untuk lebih jelasnya mengenai rincian biaya dapat dilihat pada Tabel 4.

Tabel 4. Biaya Eksplisit Rata-rata Yang Dikeluarkan Pada Pada Usahatani Padi Sawah di Kelurahan Cempaka

\begin{tabular}{clcc}
\hline No. & \multicolumn{1}{c}{ Uraian } & Biaya Eksplisit Rata-rata $(\mathrm{Rp})$ & Persentase $(\%)$ \\
\hline 1. & Pajak lahan & $3.552,38$ & 0,20 \\
2. & TKLK & $1.647 .666,67$ & 94,07 \\
3. & Saprodi & $77.896,67$ & 4,45 \\
4. & Penyusutan alat & $22.391,11$ & 1,28 \\
\hline & Jumlah & $1.751 .506,83$ & 100,00 \\
\hline
\end{tabular}

Sumber : Hasil Pengolahan Data Primer, 2020.

Dari Tabel 4, diketahui penggunaan biaya tertinggi pada tenaga kerja luar keluarga yaitu sebesar Rp. 1.647.666,67 $(94,07 \%)$. Sedangkan penggunaan biaya yang terendah ada pada pajak lahan yaitu sebesar Rp. 3,552,38 (0,20\%).

\section{Penerimaan}

Penerimaan merupakan hasil perkalian antara jumlah produksi fisik dengan harga yang berlaku komoditi tersebut. Produksi yang diperoleh rata-rata sebesar $1.265,00 \mathrm{~kg} /$ responden atau sebesar $3.513,89 \mathrm{~kg} / \mathrm{ha}$ (3,51 ton/ha), maka penerimaan dalam usahatani padi sawah tadah hujan rata-rata sebesar Rp. 6.325.000/responden atau Rp. 17.569.444,45/ha. Peningkatan penerimaan dapat terjadi kalau produksi ditingkatkan dengan syarat harga tetap, atau sebaliknya Produksi tetap dan harga dinaikan maka penerimaan dapat ditingkatkan.

\section{Pendapatan}

Pendapatan merupakan selisih antara penerimaan usahatani dengan biaya yang nyata dikeluarkan atau biaya eksplisit. Penerimaan rata-rata sebesar Rp. 6.325.000/responden atau Rp. 17.569.444,45/ha dengan biaya eksplisit rata-rata sebesarRp. 1.751.506,83/responden atau sebesar Rp. 4.865.296,74/ha maka pendapatan ratarata yang diperoleh responden dalam satu kali proses produksi sebesarRp. 4.573.493,17/responden atau Rp. 12.704.147,71/ha.

Apabila pendapatan usahatani padi sawah tadah hujan dihitung berdasarkan per kapita per bulan maka diperoleh pendapatan sebesar Rp.190.562,22/kapita/bulan. Sedangkan Upah Minimum Provinsi (UMP) menurut data Gubernur Kalimantan Selatan 188.44/0868/KUM/2019 sebesar Rp. 2.877.448.59/kapita/bulan. Apabila dibandingkan pendapatan responden per bulan per kapita dengan Upah Minimum Provinsi (UMP) Kalimantan Selatan, maka pendapatan dari usahatani padi sawah tadah hujan lebih kecil, berarti pendapatan usahatani padi sawah tadah hujan masih rendah. Berdasarkan kriteria perbandingan tersebut maka pengelolaan usahatani padi sawah tadah hujan ini harus ditingkatkan pengelolaannya secara intensif terutama dari segi teknis budidayanya sehingga diharapkan adanya peningkatan produksi dengan kualitas yang baik. Dengan demikian diharapkan dapat meningkatkan pendapatan agar usahatani tersebut dapat terus dikembangkan.

\section{KESIMPULAN}

Berdasarkan hasil penelitian, maka dapat disimpulkan sebagai berikut:

1. Produktivitas yang diperoleh dari usahatani padi sawah tadah hujan dari 
30 responden dengan luas lahan ratarata 0,36 ha adalah $1.265,00$ $\mathrm{kg} / \mathrm{responden}$ atau sebesar 3.513,89 $\mathrm{kg} / \mathrm{ha}$ (3,5 ton/ha), produksi masih tergolong sedang. Ditinjau dari aspek teknis penyelenggaraan usahatani masih dilaksanakan secara tradisional seperti pengolahan tanah dengan menggunakan tajak atau cangkul, benih tidak bermutu tidak bersertifikat dan pemupukan belum maksimal.

2. Biaya yang dikeluarkan petani rata-rata sebesar Rp. 1.751.506,83/responden atau sebesar Rp. 4.865.296,74/ha. Penerimaan rata-rata sebesar Rp. 6.325.000/responden atau Rp. 17.569.444,44/ha. Pendapatan rata-rata sebesar Rp. 4.573.493,17/responden atau Rp. 12.704.147,71/ha.

\section{DAFTAR PUSTAKA}

BIP. (2001). Dasar-Dasar Penyuluhan Pertanian dan Aplikasinya. (Issue 2001).

Erlina, Y., Elbaar, E.F., \& Wardie, J. (2020). Analisis Faktor Sosial Ekonomi Pengembangan Padi Lokal Spesifik Lokasi Di Kabupaten Kapuas Provinsi Kalimantan Tengah. 5(April), 61-68. http://snllb.ulm.ac.id /prosiding/index.php/snllb-lit/article/ view/322.

Fadholi, H. (1993). Ilmu Usaha Tani (3rd ed.). Penebar Swadaya.

Jamaluddin. (2015). Analisis Usahatani Padi Varietas Unggul Nasional Unggul Lokal dan Hibrida pada Sawah Tadah Hujan di Kecamatan Bangkinang Kabupaten Kampar. Jurnal Agribisnis, 17(1), 48-59. https://doi.org/https://doi.org/10.1918 4/jsep.v11i1.5315.
Nazir, M. (2014). Metode Penelitian (10th ed.). Ghalia Indonesia.

Pratiwi, C. A., Gunawan, D. S., \& Istiqomah, I. (2018). Analisis Ekonomi Usahatani Padi dan Kelayakan Rumah Tangga Tani di Desa Sambeng Kulon Kecamatan Kembaran Kabupaten Banyumas. JSEP (Journal of Social and Agricultural Economics), 11(1), 33. https://doi.org/https://doi.org/10.1918 4/jsep.v11i1.5315.

Suratman, Y. Y. A. (2017). Analisis Pendapatan Usahatani Cabai Besar ( Capsicum annum L.) di Desa Banua Kupang Kecamatan Labuan Amas Utara Kabupaten Hulu Sungai Tengah. Media Sains, 10(April), 72-81.

Triatmoko, E., \& Fitriadi, S. (2020). Produktivitas dan Pendapatan Usahatani Padi Lokal Varitas Mayang di Desa Malintang Lama Kabupaten Banjar. Ziraa'ah Majalah Ilmiah Pertanian, 45(3), 254-262. https://doi. org/ttp://dx.doi.org/10.31602/zmip.v4 5i3.3035.

Umaroh, R., \& Noor, T. I. (2019). Analisis Efisiensi Ekonomi Relatif Usahatani Padi Sawah Berdasarkan Luas Lahan Sawah Di Desa Sindangsari, Kecamatan Banjarsari, Kabupaten Ciamis. Jurnal Ilmiah Mahasiswa Agroinfo Galuh, 6(1), 13. https://doi.org/http://dx.doi.org/10.25 157/jimag.v6i1.1233.

Wibowo, A. D. (2016). Dinamika Ketersediaan Beras: Sebuah Studi Kasus di Kalimantan Selatan. Ziraa'ah Majalah Ilmiah Pertanian, 41(2), 242-249. https://doi.org/10.31602/zmip.v41i2.4 27. 